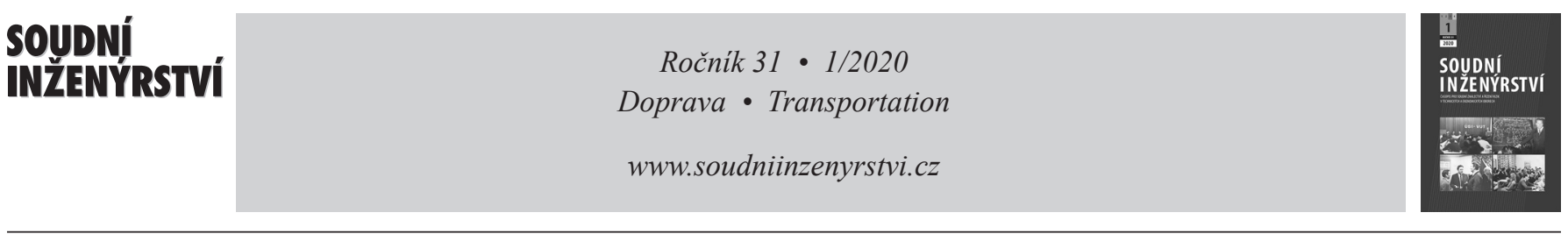

\title{
Využití bezpilotních letadel pro monitorování dopravy a analýzu
}

\author{
Utilization of Unmanned Aerial Vehicles for Traffic Monitoring and Safety Analysis
}

\author{
David Herman ${ }^{*}$
}

Vysoké učení technické v Brně, Ústav soudního inženýrství

\begin{abstract}
Abstrakt
Použití bezpilotních létajících prostředků vybavených kamerami (UAV) a umělé inteligence pro zpracování obrazu za účelem dopravního monitorování má celou řadu výhod. Jedná se zejména o možnost extrahovat extrémně přesná data o každém účastníku dopravního proudu, snadný sběr dat a extrémní mobilitu řešení. Díky pokroku ve vývoji metod pro zpracování obrazu na bázi umělých neuronových sítích a vývoji UAV v posledních letech se toto řešení pro sběr dopravních dat ukázalo jako prakticky nasaditelná. Cílem tohoto článku je ukázat praktický vhled do problematiky sběru dopravních dat pomocí dronů a využití těchto dat pro analýzu bezpečnosti provozu. Tento článek byl publikován na konferenci JuFoS 2019 [8].
\end{abstract}

Klíčová slova: dopravní monitorování, bezpečnostní analýza, dopravní konflikt, zpracování videa, UAV, dron.

\section{1. ÚVOD}

Monitorování dopravy pomocí bezpilotních prostředků a metod umělé inteligence při zpracování obrazu představuje pokrokový způsob sběru telemetrických informací o každém jednotlivém účastníku dopravního proudu. Využití této technologie má celou řadu klíčových výhod, at' už se jedná o přesnost získaných měřní, jednoduchou praktickou proveditelnost sběru dat díky extrémní mobilitě měřící platformy nebo bohatost výstupních informací v analytickém smyslu. Získané telemetrické informace o každém účastníku dopravního proudu mohou být při splnění určitých vstupních podmínek natolik přesné, že je lze využít pro detekci tzv. konfliktních situací mezi objekty, a tedy provést evaluaci analyzovaného úseku z hlediska bezpečnosti na základě jejich dopravního chování ve zkoumaném místě. Analýzy založené na trajektoriích a interakcích mezi objekty

Dodáno do redakce: 14. 2. 2020

Recenzni rízení: od 17. 2. 2020 do 18. 2. 2020

\begin{abstract}
Using unmanned aerial vehicles (UAVs) and artificial intelligence (AI) image processing for traffic monitoring is amongst the state-of-the-art ways of acquiring telemetry information about the individual participants of traffic flow. Utilization of this technology has several key advantages, be it, for example, measurement accuracy, simplicity and practicality of data collection due to extreme measurement platform mobility or, finally, richness of the output information from the traffic-analysis point of view. Even though using of aerial data for traffic analysis is already a thoroughly tested and discussed method, it has not been widely used in practice until nowadays, when technological progress in the field of UAVs and AI has made it highly feasible. The aim of this article is to provide with practical overview of UAVs usage in traffic analysis for automatic detection of conflict-situations and evaluation of road nodes in terms of safety. This article has been published at JuFoS 2019 conference [8].
\end{abstract}

Keywords: traffic monitoring, safety analysis, traffic conflict, image processing, UAV, drone.

byly dříve aplikovatelné pouze na simulovaných datech, nebot' data $\mathrm{z}$ reálného provozu nebylo prakticky možné získat v požadovaných přesnostech a v širším měřítku. Teprve letecké snímkování za účelem monitorování dopravy a nedávný vývoj autonomních bezpilotních prostředků (tzv. UAV) a pokrok v umělé inteligenci ve zpracování obrazu umožnil praktické nasazení př́istupů pro detekci tzv. skoro-nehod na základě analýzy pohybů. Nicméně přesná dopravní data mají další uplatnění, a to např. v automatické kalibraci simulačních dopravních modelů, př́ípadně v běžných dopravních studiích. O přesná data mají rovněž zájem výzkumné týmy automobilek v kontextu vývoje systémů automatického řízení.

Cílem tohoto přehledového př́spěvku je ve stručnosti popsat jednotlivé základní prvky př́stupu pro evaluaci křižovatek z hlediska bezpečnosti s využitím UAV, metod umělé inteligence pro zpracování obrazu a indikátorů konfliktů. 


\section{NATÁČENÍ VIDEÍ A SBĚR DAT}

Získání přesných telemetrických dat o každém jednotlivém účastníku dopravního proudu pomocí analýzy obrazu je podmíněno zejména vhodným obrazovým vstupem. Dalším významným faktorem je kvalita vlastních algoritmů zpracování obrazu, složitost scény jak z pohledu dopravního toku, tak i platnosti zjednodušujících
- geometrická deformace zachyceného snímku, způsobená nedokonalostí optické soustavy kamery - tzv. distorze. Tato nedokonalost může být odstraněna (a $\mathrm{v}$ praxi se vždy odstraňuje) na základě dat z kalibrace kamery. Toto odstranění ale nemusí být zcela dokonalé, proto je nutno uvažovat určitou reziduální geometrickou deformaci zachyceného snímku.

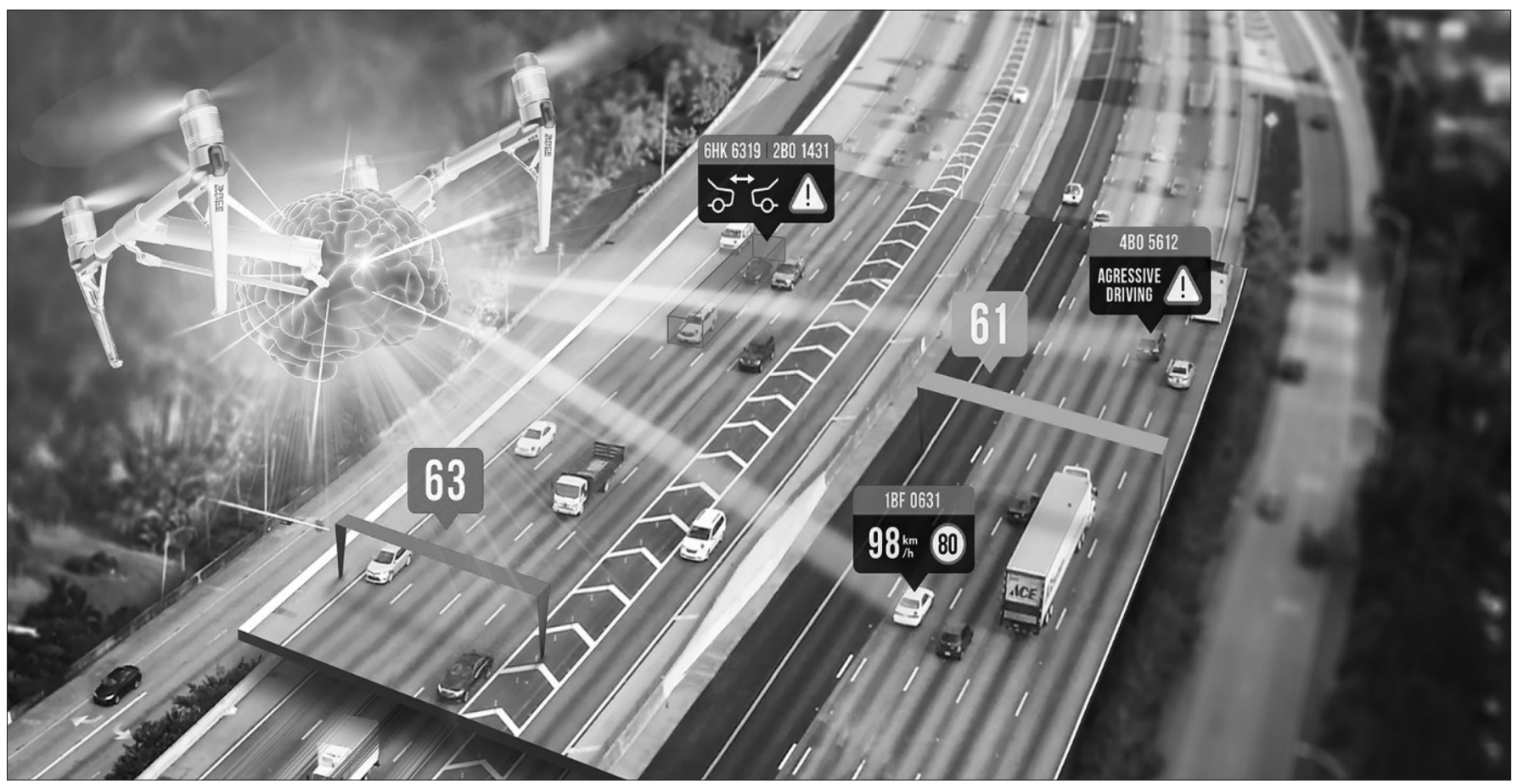

Obr. 1 Ilustrace systému pro monitorováni dopravy pomoci UAV a analýzy obrazu. Tento systém poskytuje trajektorii každého jednotlivého účastnika dopravního proudu. Nad tímto souborem trajektorii pak běži dopravně-analytické výpočty pro identifikaci např. konfliktnich situací, nebezpečného chováni apod. [6]

Fig. 1 Illustration of the system for traffic monitoring using aerial view. The output from the image processing is trajectory data about each user-participant. Telemetry data is used for automatic detection of conflict situations [6].

předpokladů ve vlastním SW zpracování (aproximace povrchu vozovky rovinou apod.), přesnost samotné georegistrace atd. Jedná se tak o soubor parametrů, přičemž některé se vzájemně ovlivňují a jejich vazby jsou v mnoha př́ípadech komplexní. Z pohledu př́ijemce dat se jedná vždy o pareto-optimum mezi plochou, kterou je možné jedním prostředkem pokrýt, a přesností lokalizace objektů, které může být v rámci této plochy dosaženo. Nadto do kompozice záběru vstupuje ještě další významný faktor, kterým jsou legislativní omezení ve využíaání UAV pro sběr obrazových dat z pozemních komunikací. Cílem této kapitoly je stručně nastínit citlivostní analýzu systému a tuto dát do kontextu s požadavky na kompozici scény při natáčení a legislativních omezeních ve využívání UAV pro komerční/vědecké účely.

\subsection{Citlivostní analýza systému/přesnost měření}

Odhad přesnosti a použitelnosti zamýšleného řešení byl vykonán pomocí počítačových simulací následovně. Na základě parametrů hardwarové platformy dronu a jeho optické soustavy jsme specifikovali zjednodušený matematický model odhadu polohy objektu nacházejícího se na zemi ze snímků zachycených během letu dronu. Tento matematický model byl implementován do aplikace, která simulovala případový scénář: dron letící nad dopravní scénou snímá kamerou objekty pohybující se v této scéně a získává z těchto pozorovaní jejich polohu. Při tomto procesu nastávají/mohou nastat/projevit se následující chyby měření a nepřesnosti použitého hardwaru:

- poloha referenčních bodů ve skutečném světě může být získána nepřesně - bud' kvůli nepřesnému odhadu polohy samotným měřicím zařízením (např. diferenciální GPS jednotka), nebo kvůli nepřesnosti mapových podkladů, nebo kvůli lidské chybě (např. nepřesná aplikace měřicího zařízení),

- poloha nasnímaných objektů (at’ už jde o referenční bod nebo o vozidlo) v zachyceném snímku může být nepřesná, a to $\mathrm{z}$ následujících důvodů:

- světelný paprsek může být vychýlen z přímky z důvodu atmosférické turbulence nebo světelné aberace,

- nepřesná lokalizace objektu ve snímku (nepřesnost algoritmu detekce, resp. lokalizace daného objektu na snímku),

- objekty mohou být vertikálně posunuty vůči ideálně rovné ploše scény (způsobeno terénem), 
Tab. 1 Sumarizace ziskaných informaci z citlivostni analýzy dílčich parametrů na přesnost lokalizace [7].

Tab. 1 Summary of sensitivity analysis results on the accuracy of localization [7].

\begin{tabular}{|c|c|c|c|}
\hline Zdroj chyby | Aspekt & Velikost chyby & Počet referenčních bodů & Vzdálenost od středu scény/snímku \\
\hline Poloha referenčních bodů ve světě & Lineárně roste & Klesá odmocninou & Kvadraticky roste \\
\hline Poloha referenčních bodů v obraze & Lineárně roste & Klesá odmocninou & Kvadraticky roste \\
\hline Horizontální posunutí referenčního bodu & Lineárně roste & Klesá odmocninou & Kubicky roste \\
\hline Poloha odhadovaného objektu v obraze & Lineárně roste & - & Konstantní \\
\hline Horizontální posunutí referenčního bodu & Lineárně roste & - & Lineárně roste \\
\hline Geometrická distorze obrazu & $\begin{array}{l}\text { Nelineárně roste (záleží } \\
\text { na typu distorze) }\end{array}$ & - & $\begin{array}{l}\text { Nelineárně roste (záleží na typu } \\
\text { distorze) }\end{array}$ \\
\hline
\end{tabular}

Všechny uvedené chyby, kromě poslední, lze považovat pro zjednodušení za nezávisle náhodné a mající charakter normálního rozdělení. Výjimkou je chyba geometrické deformace zachyceného snímku, která je uvažována jako závislá a konstantní, protože parametry kamery ani její optická soustava se v průběhu snímání nemění. Citlivostní analýza byla provedena pomocí prŕístupu Monte-Carlo vzorkováním náhodných chyb. Pro každou kombinaci chyb byl proces pozorování scény a odhadu polohy vozidla proveden opakovaně za účelem propagace nepřesností způsobených zmíněnými chybami. Výsledky analýzy přehledně shrnuje tab. 1.

Simulační algoritmus byl následně využit pro odhad ideální pozice dronu pro zachycení co největší plochy dopravní scény s chybou pod určitou mezní hodnotu. Ukázka výstupu takového vyhodnocení je zobrazena na grafu v obr. 2.
Citlivostní analýza ukázala, že za běžných podmínek je možno při soudobé technologii UAV dosáhnout vysoké přesnosti v lokalizaci pozemních cílů $(<0,5 \mathrm{~m})$, a tedy získat velmi přesná telemetrická data o jejich pohybu. Využití UAV tak představuje velmi přesný a nezávislý měřicí systém pro mikroskopické analýzy dopravního toku, který je pro pozorovaného prakticky neviditelný, a tedy nedochází k ovlivnění chování účastníků dopravního proudu vlastním měřením.

\subsection{Kompozice scény vhodná pro extrakci trajektorií}

Ideálem při pořizování leteckých videí určených pro dopravní analýzu je pohled z ptačí perspektivy, při kterém osa optické soustavy kamery svírá se zemským povrchem úhel blížící se $0^{\circ}$ (obr. 3 vlevo). Důvodem tohoto požadavku je dosažení minimální

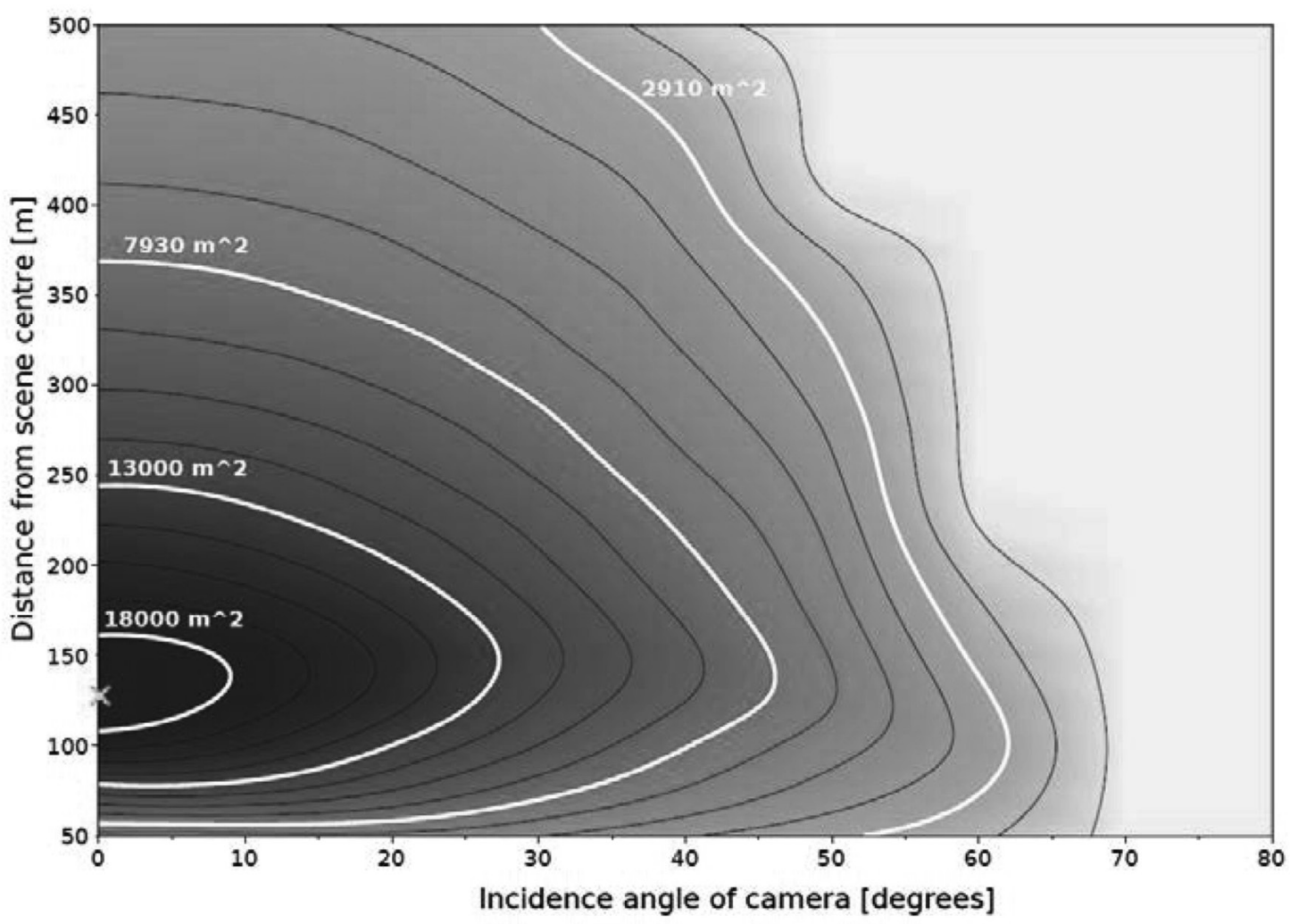

Obr. 2 Závislost mezi polohou dronu a velikostí plochy, na niž je dron schopen odhadovat polohu objektů s prümérnou presností pod mez 0,5 m. Ideální poloha dronu (zelený křižek) je v takovém př́padě 125 metrů přimo nad středem pozorované oblasti. Pokud by z bezpečnostních dưvodů nebylo možné mít menši incidenčni úhel než 45 stupňu, tak ideálni výška by při této konfiguraci byla 140 metrů [7].

Fig. 2 The dependency between the position of UAV (distance and angle of incidence) and area covered with localization accuracy up to

0.5 meters. In this case, the ideal UAV location is 125 meters directly above the center of the observed area (marked by a green cross). If the angle of incidence is limited to at least 45 degrees for safety reasons, the ideal distance for such configuration will be 140 meters [7]. 


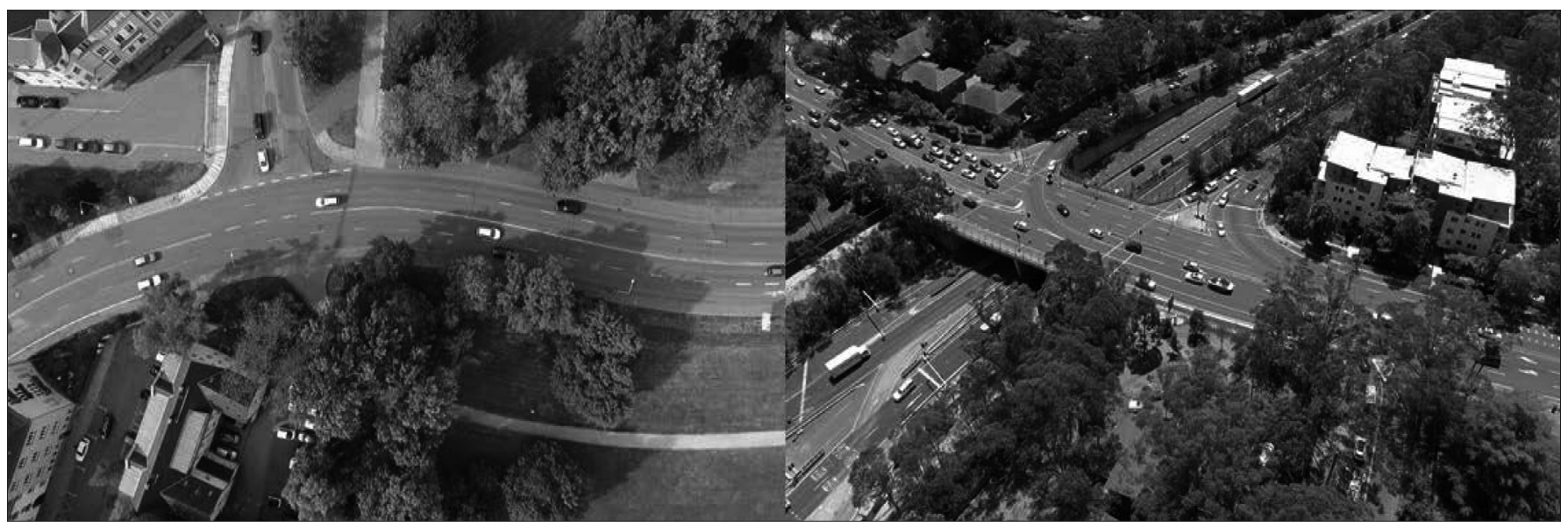

Obr. 3 Vlevo snimek z dronu za ideálních podminek pro dopravni analýzu; vpravo snimek obsahujíci statické i dynamické okluze, které mohou vést $k$ četným chybám při automatickém zpracováni videí (sledováni objektů) [6].

Fig. 3 Left image shows an ideal scene composition for extreme accurate extraction of traffic data; right image shows situation with a lot of potential dynamic and static occlusions which could lead to worse output [6].

chyby lokalizace objektu ve scéně při převodu pozice objektu z obrazového prostoru do prostoru reálného světa. Čím větší je incidenční úhel, tím větší chyba může vzniknout při geo-lokalizaci objektu a následné dopravní analýze. $Z$ důvodu velikosti možné vzniklé chyby při geo-lokalizaci vozidla, a také omezených schopností rozpoznávacího systému, by tento úhel neměl být menší než $45^{\circ}$.

$\mathrm{Z}$ pohledu automatizace extrakcí trajektorií pohybu objektů v leteckých videozáznamech je vhodné nalézt takový záběr na oblast zájmu, ve kterém se vyskytuje minimální množství statických a dynamických vizuálních překrytí. I přes možnou schopnost systému detekovat okluze v obraze a spojovat trajektorie vyskytující se na jejich rozhraní je nutno v zájmu zvýšení kvality výsledné dopravní analýzy, automatizace extrakce trajektorií a minimalizace manuální kontroly kvality a oprav pořizovat takové letecké videozáznamy, kde je četnost částečných i úplných okluzí minimalizována. Obr. 3 (vpravo) ilustruje př́klad scény, kterou je obtížné automaticky analyzovat $\mathrm{z}$ důvodu většího výskytu okluzí v obraze.

Rozlišení objektů v obraze se odvíjí od výšky, ze které je letecký záznam pořizován, zorného pole optické soustavy kamery a rozlišení snímacího čipu kamery. Nejmenší velikost objektu $\mathrm{v}$ obraze, který by měl být systém schopný bezpečně rozpoznat a klasifikovat, je $32 \times 32$ obrazových bodů (toto rozlišení už nese dostatečné množství vizuální informace pro robustní detekce a klasifikaci objektu do několika tříd pomocí strojového učení). $\mathrm{K}$ této hodnotě tak musí být parametrizováno záznamové zařízení (rozlišení videa, objektiv apod.). Před samotným procesem extrakce trajektorií $\mathrm{z}$ obrazu je pořízený video záznam $\mathrm{v}$ rámci georegistrace stabilizován. Malé otřesy způsobené vibracemi motorů UAV ( $\mathrm{v}$ případě řiditelného prostředku) nebo záchvěvy větru nemají zásadní dopad na přesnost extrahovaných trajektorií z obrazu (dnešní drony již poskytují extrémně stabilní obraz nezatížený těmito „vysokofrekvenčními“ artefakty). Je velmi žádoucí minimalizovat pohyb snímacího zařízení v prostoru po započetí nahrávání video záznamu. Z důvodu snadné stabilizace a georegistrace videozáznamu je nezbytné po celou dobu pořizování záznamu udržovat oblast zájmu v obraze.

\subsection{Legislativa}

Legislativní omezení ve využívání UAV má zásadní vliv na kompozici scény během vlastního natáčení. Legislativa ve využití UAV se liší mezi jednotlivými státy (celosvětově), ačkoliv se pravidla $\mathrm{v}$ oblasti vyspělých ekonomik přibližují. Nadto v mnoha státech je možno získat výjimku, a provádět tak natáčení prakticky za ideálních podmínek, což je ptačí pohled. Situace se dále komplikuje i samotnou platformou, která je použita. Jiná pravidla platí např. pro vázané balóny, jiná pro bezpilotní systémy. U bezpilotních systémů je dále determinující maximální vzletová hmotnost stroje, přičemž s rostoucí hmotností dochází ke zvyšování nároků na provoz systému. Roli rovněž hraje, zda se jedná o rekreační použití UAV prostředku, kde jsou omezení významně relaxována, nebo o využití pro komerční, experimentální či výzkumné účely. V př́ípadě České republiky je používání těchto prostředků regulováno tzv. Doplňkem X leteckého predpisu L 2. Obecně platí, že využívání menších UAV $(<1$ kg; dnešní malé drony tuto podmínku splňují) pro natáčení pozemních komunikací není legislativně zcela znemožněno v naprosté většině zemí. Limitována bývá často maximální letová výška, a to ve většině př́ípadů na 120 metrů (v ČR se jedná o 300 metrů - mimo mraky), a dodržení bezpečné vzdálenosti od dálnice (není možný let/průlet nad dálnicí, min. horizontální vzdálenost se pohybuje v rozmezí 50-100 metrů). Let nad pozemní komunikací je tak pro menší UAV v mnoha státech legislativně možný (napřr. Německo), nebot' je uvedeno pouze doporučení dodržovat tzv. bezpečnou vzdálenost. V praxi je však obecně akceptováno pravidlo, že bezpečná horizontální vzdálenost je rovna výšce letu dronu, neboli že incidenční úhel záběru kamery je právě 45 stupňů. V poslední době je však i tato podmínka čím dál více relaxována a často se nastavuje bezpečná vzdálenost pevně, bez ohledu na výšku letu, a to na cca 45 metrů. Z pohledu legislativy tak lze uvažovat následující konfiguraci:

- maximální letová výška dronu - 120 metrů,

- incidenční úhel záběru k optické ose kamery - nejvíce 45 stupňů, zpravidla méně.

Tato konfigurace není omezující z pohledu využití UAV pro získání velmi přesné telemetrie pohybu pozemních objektů, a tedy 


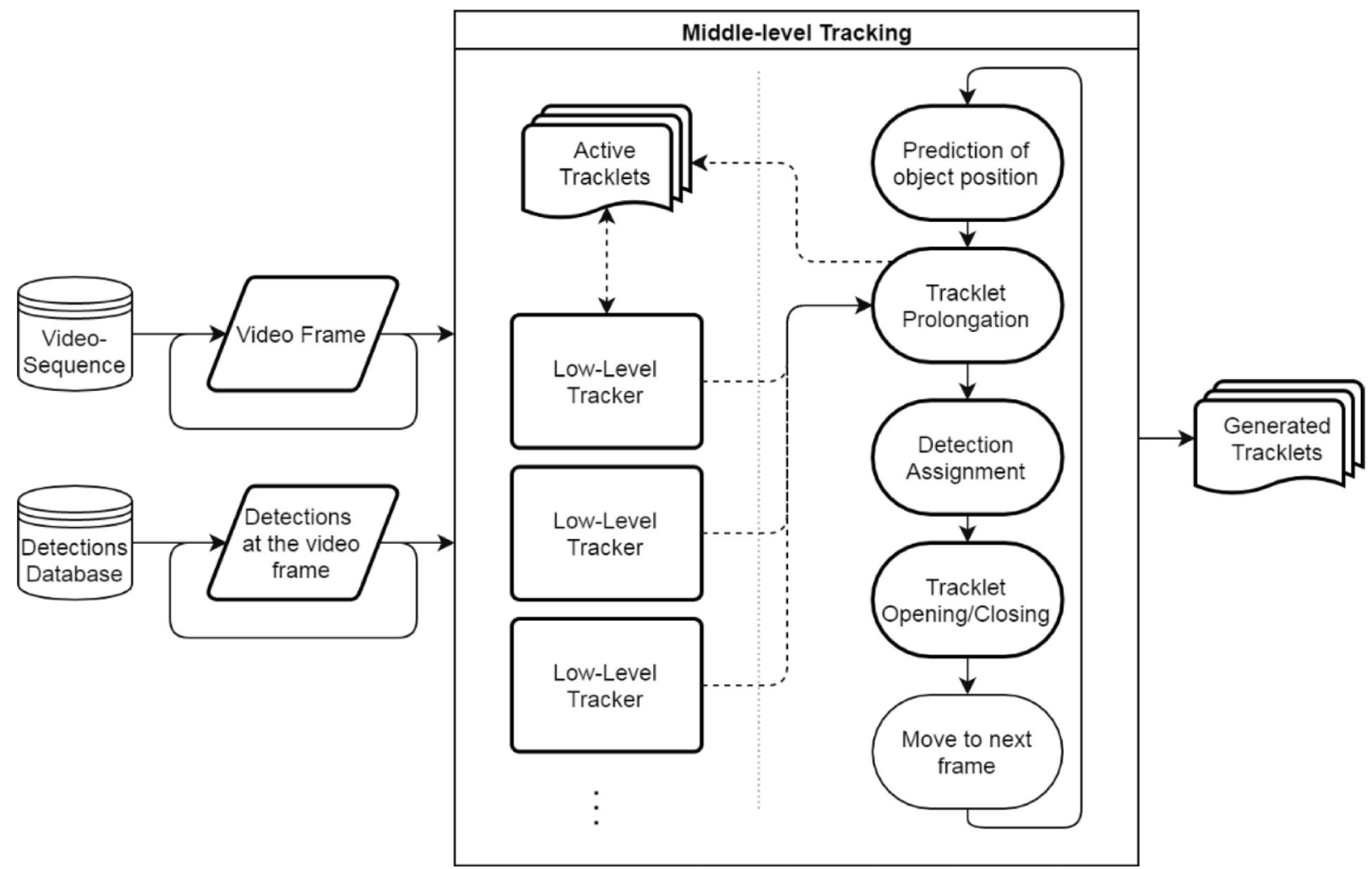

Obr. 4 Princip navržené architektury middle-level trackingu pro extrakci trackletů. Algoritmus postupně vyčitá ze vstupní video sekvence snimky a zároveň $k$ nim odpovidajicí detekce. Tato data následně zpracovává a generuje seznam trackletů [3].

Fig. 4 SW architecture of image processing system for extraction of tracklets (short trajectories) from aerial views [3].

legislativa v mnoha př́ipadech nepředstavuje koncepční překážku $\mathrm{v}$ tomto prístupu.

\section{EXTRAKCE TRAJEKTORIÍ}

Extrakce trajektorií je postavena na kombinaci detekce objektů v obraze a jejich následného trackování v dalších po sobě jdoucích snímcích. Detekce identifikuje ve snímcích objekty zájmu, tedy vozidla a další účastníky dopravního proudu. Vlastní tracking detekovaných objektů je rozdělen na tři úrovně, a to:

- extrakce trackletů (anglický termín označující kratší trajektorie určené k napojení pro získání spojitého popisu pohybů objektů ve scéně),

- správa trackletů,

- napojování trackletů.
Architektura systém je navržena tak, aby detekce a spojování trackletů bylo možno vykonávat odděleně od samostatné extrakce trackletů a jejich správy. Z trackletů, které představují části trajektorií objektů ve scéně, se vytvoří finální trajektorie jejich spojením, opravením a následným vyhlazením (viz obr. 4 High-level tracking).

Detekční systém staví na využití hlubokých neuronových sítí, které značně překonávají dřívější přístupy, založené na kaskádových klasifikátorech, modelech pozadí atd. Mezi nejznámější přístupy v této oblasti patří R-CNN, Fast R-CNN, Faster R-CNN a R-FCN. $\mathrm{Z}$ těchto meta-frameworků bude využit Faster R-CNN, nebot' je možné jej relativně dobře přizpůsobit $\mathrm{k}$ detekci velmi malých objektů napříč snímky s vysokým rozlišením.

Low-level tracking reprezentuje řešení problému identifikace sledovaného objektu v následujícím snímku (obr. 5). Na základě testů se ukazuje, že i v této části přístupy založené na hlubokých

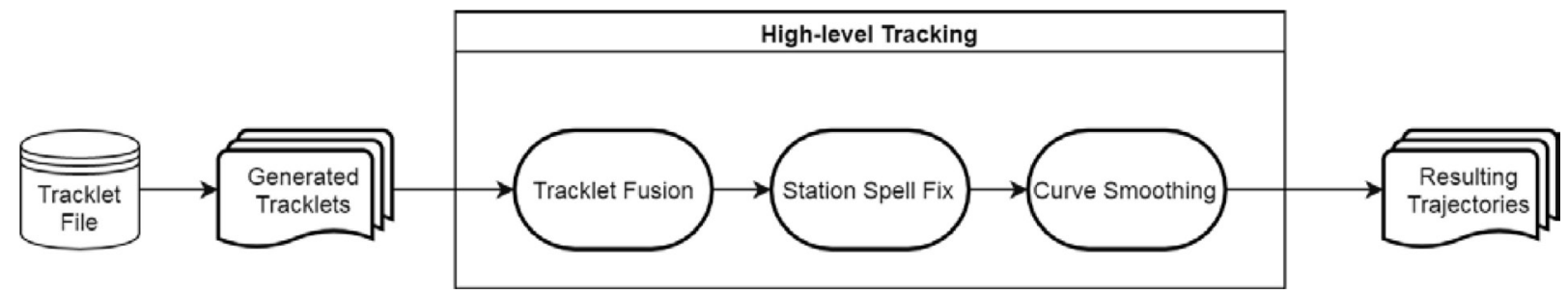

Obr. 5 Princip navrženého high-level trackeru. Na vstupu se zpracují všechny vygenerované tracklety z videa zároven̆ - nejprve se spojí relevantní části, aplikuje se opravení prípadných nespojitostí/chyb a nakonec se trajektorie vyhladi [3].

Fig. 5 SW architecture of high-level tracker for linking of tracklets to provide continuous and smoothed trajectories [3]. 
neuronových sítích překonávají významně jiná řešení (částicové filtry, SVM apod.). S ohledem na provedené testy budeme systém budovat na modifikované architektuře neuronové sítě DSiamM. Cílem modifikací bude jednak zvýšení robustnosti v doméně našeho problému, a jednak značné optimalizace za účelem vyšší rychlosti zpracování.

\section{ZÁVĚR}

Cílem tohoto článku bylo stručné představení systému pro monitorování chování účastníků dopravního proudu pomocí kombinace bezpilotního prostředku a pokročilého zpracování obrazových dat, a to za účelem získání velmi přesných telemetrických informacích pro následnou detekci tzv. konfliktních situací a evaluaci křižovatky z hlediska bezpečnosti. Jedná se o velmi komplexní úlohu jak po stránce technické realizace (optická soustava, přesnost měření), obrazového zpracování dat (metody detekce, klasifikace a sledování objektů v obraze), zpřesňování měření (metody filtrace), interpretace výsledků (detekce konfliktních situací a jejich význam) a legislativního rámce (kde a za jakých podmínek lze využívat bezpilotní letouny). Článek se soustředil pouze na vybrané části této problematiky, a to pouze přehledově. Dílčí problematika bude detailně řešena a publikována v samostatných příspěvcích, přičemž mezi klíčové části bude patřit analýza citlivosti systému, zpracování obrazu, detekce konfliktů a jejich intepretace z pohledu bezpečnosti (zde se očekává hlavní prínos práce).

\section{PODĚKOVÁNí}

Údaje $\mathrm{v}$ článku jsou použity/převzaty z materiálů získaných v rámci projektu TAČR - TH02010882 Systém preemptivni bezpečnostní analýzy silničnich uzlù a dopravního proudu, na kterých se podílí firma RCE systems s.r.o. spolu s VUT Brno (Fakulta stavební a Ústav soudního inženýrství). Poděkování patří taktéž prof. Ing. Vladimíru Adamcovi, CSc. za metodické vedení, dále pak realizačnímu týmu na Ústavu automatice inženýrských úloh a informatiky a Ústavu pozemních komunikacích, jmenovitě doc. Ing. Tomáši Apeltauerovi, Ph.D. a Ing. Jiřímu Apeltauerovi, $\mathrm{Ph} . \mathrm{D}$., stejně tak jako realizačnímu týmu na straně společnosti RCE systems s.r.o.

\section{LITERATURA}

[1] AUTEY, J., SAYED, T., ZAKI, M. H. Safety evaluation of right-turn smart channels using automated traffic conflict analysis. Accident Analysis and Prevention, 2012, 45(Supplement C), s. 120-130. ISSN 0001-4575.

[2] LU, G., LIU, M., WANG, Y. a kol. Quantifying the Severity of Traffic Conflict by Assuming Moving Elements as Rectangles at Intersection. Procedia - Social and Behavioral Sciences, 2012, 43(Supplement C), s. 255-264, ISSN 1877-0428, $8^{\text {th }}$ International Conference on Traffic and Transportation Studies (ICTTS 2012)

[3] APELTAUER, J., BABINEC, A., HERMAN, D. a kol. Automatic Vehicle Trajectory Extraction for Traffic Analysis from Aerial Video Data. ISPRS - International Archives of the Photogrammetry, Remote Sensing and Spatial Information Sciences, 2015, s. 9-15.

[4] SAUNIER, N. AutomatedMethods for Surrogate Safety Analysis. 2014, [online]. URL http://n.saunier.free.fr/saunier/stock/14-0825-dcdot.pdf

[5] MAHMUD, S. S., FERREIRA, L., HOQUE,M. S. a kol. Application of proximal surrogate indicators for safety evaluation: A review of recent developments and research needs. IATSS Research, 2017, 41(4), s. 153-163. ISSN 0386-1112.

[6] Stránky projektu DataFromSky [online]. c 1999-2004, poslední aktualizace 27. 03. 2019 [cit. 2019-03-31]. Dostupné z: <www. datafromsky.com>.

[7] BABINEC, A., APELTAUER, J. On Accuracy of Position Estimation from Aerial Imagery Captured by Low-flying UAVs., International Journal of Transportation Science and Technology 2017, doi: http://dx.doi.org/10.1016/j.ijtst.2017.02.002, IJTST 22.

[8] HRDLIČKA, T., OPÁLKOVÁ, T., URBÁNEK, M. a kol. Sbornik př̀spěvků konference Junior Forensic Science, Brno, 2019, Vysoké učení technické v Brně, Ústav soudního inženýrství, ISBN 978-80-214-5730-0, [cit. 2020-02-10]. Dostupné z: < http://www.jufos.cz/wp-content/uploads/2015/11/ Sborn\%C3\%ADk-JUFOS-2019 final.pdf>.

\section{Správná citace:}

HERMAN, D. Využití bezpilotních letadel pro monitorování dopravy a analýzu. Soudní inženýrství, 2020, 31(1), 3-8. DOI: http://dx.doi.org./10.13164/SI.2020.1.3. ISSN 1211-443X. 